\title{
Patterns of polychlorodibenzo-p-dioxins and furans and study the dietary intake in commercialized orange in Egypt
}

\author{
Mostafa M. H. Khalil ${ }^{1 *}$, Ashraf M. El-Marsafey ${ }^{2}$, Yasser M. Nabil ${ }^{2}$ and Muhammad M. Issa ${ }^{2}$ \\ ${ }^{1}$ Department of Chemistry, Faculty of Science, Ain Shams University, Cairo, 11566, Egypt, \\ ${ }^{2}$ Central Laboratory of Residue Analysis of Pesticides and Heavy Metals in Food (QCAP), Agricultural Research Center \\ (ARC), Ministry of Agriculture and Land Reclamation, Dokki, Giza, 12311, Egypt.
}

ARTICLE INFO

Article history:

Accepted 26 March 2017

Keywords:

$P C D D / F s$;

$H R G C / M S$;

Dietary intake;

Orange;

Egypt.
Received 06 March 2017

\begin{abstract}
A B S T R A C T
A total of 18 orange samples were collected from 9 different governorates in Egypt and analyzed for dioxins, consisting of polychlorodibenzo-p-dioxins (PCDDs) and polychlorodibenzofurans (PCDFs), using High Resolution Gas Chromatography - High Resolution Mass Spectrometer (HRGC-HRMS). The mean concentration of $\Sigma \mathrm{PCDD} / \mathrm{Fs}$ in orange samples was $1.8596 \mathrm{pg} / \mathrm{g}$ whole weight (w.w.). 1,2,3,4,6,7,8,9-Octachlorodibenzo-p-dioxin (OCDD) was the dominant congener of $\mathrm{PCDD} / \mathrm{Fs}$ in orange samples. The Toxic Equivalency (TEQ) concentrations of PCDD/Fs were calculated using the Toxicity Equivalent Factors (TEF) established by the World Health Organization (WHO) in 2005. The mean TEQ concentration of $\Sigma \mathrm{PCDD} / \mathrm{Fs}$ in orange samples was 0.1616 pgWHO-TEQ $2005 / \mathrm{g}$ w.w. This study showed that the average TEQ concentration of $\Sigma$ PCDDs (0.1061 $\mathrm{pgWHO}^{-T E Q}{ }_{2005} / \mathrm{g}$ w.w.) is higher than the average TEQ concentration of $\Sigma \mathrm{PCDFs}\left(0.0555 \mathrm{pgWHO}-\mathrm{TEQ}_{2005} / \mathrm{g}\right.$ w.w.) which contributed about $65.66 \%$ from the total TEQ concentration of $\sum \mathrm{PCDD} / \mathrm{Fs}$ in commercialized orange in Egypt. This study showed that the PCDD/Fs levels in orange were lower than the maximum permissible limits of Egyptian Standardization and European Community $\left(0.30 \mathrm{pgWHO}-\mathrm{TEQ}_{2005} / \mathrm{g}\right.$ w.w.). The consumption of Egyptian people for orange attained according to GEMS/Food World Health Organization (WHO) consumption rate of orange for the Middle Eastern people is $38 \mathrm{~g} /$ person/day, which showed that the Estimated Daily Intake (EDI) of $\Sigma \mathrm{PCDD} / \mathrm{Fs}$ of the Egyptian consumer is $0.1023 \mathrm{pg}$ WHO-TEQ/kg body weight/day lower than the WHO acceptable daily intake which is $4 \mathrm{pg}$ WHOTEQ/ kg b.w/day.
\end{abstract}

\section{Introduction}

Polychlorinated dibenzo-p-dioxins and dibenzofurans (PCDDs and PCDFs) are two groups of chemicals within the persistent organic pollutants (POPs) found in the environment because of their persistent, toxic, and bioaccumulative properties. Furthermore, they are the most toxic POPs ${ }^{[1]}$. The two families of POPs consist of 75 PCDDs and 135 PCDFs theoretical individual congeners, based on the number and position of chlorine atoms in the chemical structure ${ }^{[2]}$. Although they are 210 PCDD/Fs congeners, only 17 (those with a 2,3,7,8 substitution) have so far been found to be toxic. Among them, the most toxic compound is 2,3,7,8tetrachlorodibenzo-p-dioxin or TCDD. The toxicity of other PCDD/Fs is measured in relation to TCDD.

\footnotetext{
* Corresponding author.

E-mail address: Khali162@yahoo.com
} concentration, a highly competent system, which allows on the basis of toxic equivalents (TEQ), has been developed for humans and wildlife ${ }^{[3]}$.

In general, PCDD/Fs compounds are of unintentional anthropogenic nature linked to several industrial processes that include thermal and combustion processes, waste incineration, industrial reservoir source, metal smelting and refining and production of pesticides $[4,5]$.

PCDDs and PCDFs may be transported over long distances from their source and travel via water, air and ground. Because of their high stability, low volatility and high resistance to degradation, they can remain long periods with half-lives between 7 and 10 years ${ }^{[6]}$. These characteristics render dioxins to be highly persistent
PCDD/Fs have well described toxicities at extremely low inter-comparison of toxicities between different isomers 
pollutants that experience bioaccumulation and bio magnification phenomena, so they can access into the feed and food chain ${ }^{\text {77-10] }}$.

Oranges represent around 30 percent of the total Egyptian fruit production and 65 percent of citrus production. Egypt is one of the world's leading orange producers and exporters. Egyptian orange production is high yielding and competitive due to the availability of irrigation water (the Nile), suitable climatic conditions, good soil, low labor costs, an early harvest compared to other major producers in the region, and Egypt's proximity to major importing countries. Egypt is the sixth orange producer in the world after Brazil, China, US, EU, and Mexico. Several orange varieties are produced in Egypt but the dominant varieties are six (Baladi Orange, Valencia Orange, Blood Orange, Navel Orange, Khalily Orange and Sweet Orange). Valencia and navel are the main exported varieties while the others are used more for domestic consumption ${ }^{[11]}$.

A wide variety of extreme health effects have been related to high exposure to dioxin derivatives, such as growth retardation of the fetus and infants, developmental defects, reproductive effects, chloracne, hormonal dysfunctions, mood alterations, reduced mental performance, endometriosis, changes in white blood cells, dental defects and diabetes ${ }^{[12-17]}$.

Since 1990s food has been identified as a pathway of human exposure to dioxin compounds. Dietary intake contributes about $90-98 \%$ of the total daily dioxin intake of the general population $[\mathbf{1 8}, \mathbf{1 9 ]}$. The World Health Organization (WHO) has established a tolerable daily intake (TDI) range of 1-4 pg TEQ (Toxic Equivalency)/kg b.w. (body weight) for dioxins ${ }^{[20]}$. Likewise, a tolerable weekly intake (TWI) of $14 \mathrm{pg}$ WHO-TEQ/kg b.w. (body weight) has been set up by the European Union through the Scientific Committee on Food ${ }^{[21]}$.

Therefore, the aim of this study is the assessment of the risk on the human as dietary exposure to dioxins in consumed orange in Egypt through estimating their dietary intake relative to the acceptable daily intakes stated by the World Health Organization (WHO).

\section{Materials and methods}

\section{Sampling}

The procedures of sampling were performed following the Codex Alimentarius Commission regulation ${ }^{[22]}$. A total of 18 orange samples were purchased from 9 different governorates (Qaliubiya, Giza, Alexandria, Ismailia, Sharkia, Fayoum, Menoufiya, Beni Suef and Gharbiya) in Egypt to determine levels of Polychlorinated dibenzo-p-dioxins (PCDDs) and dibenzofurans (PCDFs). Samples were collected during the years 2015-2016 and were homogenized using a blender and stored at $-20^{\circ} \mathrm{C}$ until analysis.

\section{Chemicals and reagents}

All solvents used were analytical grade and purity not less than 99\%. Silica gel and basic alumina were purchased from Aldrich (Brockmann I, Standard grade, Milwaukee, USA). Calibration standard solutions, labeled standard and injection solutions specified in Environmental Protection Agency (EPA) Method 1613B were obtained from Cambridge Isotopes Laboratories (Andover, USA).

\section{Apparatus and instrument}

Soxhlet (50mm ID, $200 \mathrm{ml}$ capacity with $500 \mathrm{ml}$ flask), Top bench balance" Mettler Toledo" ranged from $0.1 \mathrm{mg}$ to 210 , Electrical apparatus for sample homogenization (e.g Bamix), Thimble (43mm ID*123mm H) to fit Soxhlet, Rotary evaporator (Heidolph VV2000), Calibrated Micro-liter pipettes and Heating Electromantle (Cat. No EM0500/C to fit $500 \mathrm{ml}$ round-bottom flask).

High Resolution Gas Chromatography/High Resolution Mass Spectrometry (HRGC/HRMS).The High Resolution Mass Spectrometry (Micromass Auto-Spec Ultima) attached to GC chromatography (Agilent 6890 N).The GC equipped with Auto injector (Agilent 7683 series), Split/Splitless injection port for capillary column and a DB-5ms fused silica column $(60 \mathrm{~m} \times 0.25 \mathrm{~mm} \times$ $0.25 \mu \mathrm{m})$.

\section{Method of analysis}

\section{Extraction}

Orange samples were grinded well. A known weight of samples $(25 \mathrm{~g})$ was spiked with known amounts of mixture of labeled PCDD/Fs. Next, samples were extracted by soxhlet for at least 18-24 $\mathrm{h}$ with Dichloromethane /Hexane 1/1 v/v. The extract was rotary evaporated and concentrated to near dryness. Complete removal of the solvent was performed using a stream of nitrogen. The extract residue was dissolved in $5 \mathrm{ml}$ of $\mathrm{n}$-hexane for cleanup.

\section{Cleanup and purification process}

These steps were conducted according to U.S EPA 1613(B) Method [23], using Anthropogenic, Multilayer silica gel, Alumina and active Carbon column.

\section{HRGC/HRMS analysis}

The qualitative and quantitative analyses of PCDD/Fs congeners and dl-PCBs congeners were performed using GC/HRMS in the selected ion monitoring mode at a resolution $\geq 10,000$. Separation of congeners was carried out using a capillary column (60m length, $0.25 \mathrm{~mm}$ ID, and $0.25 \mu \mathrm{m}$ thickness) coated with a DB-5 stationary phase. Helium was used as a carrier gas at a flow rate of $1 \mathrm{ml} / \mathrm{min}$. The temperature of the injector and the interface were $280{ }^{\circ} \mathrm{C}$, respectively. The column temperature program was as follows: initial temperature was $90-220^{\circ} \mathrm{C}$, at $15^{\circ} \mathrm{C} / \mathrm{min}$, then kept at $220^{\circ} \mathrm{C}$ for $15 \mathrm{~min}$ then raised again from $220-290{ }^{\circ} \mathrm{C}$ at a rate of 8 ${ }^{\circ} \mathrm{C} / \mathrm{min}$ and kept at $290^{\circ} \mathrm{C}$ for $17.6 \mathrm{~min}^{[23]}$.

\section{Quantitative determination}

PCDD/Fs were performed by an isotope dilution method using relative response factors previously obtained from five standard solutions. The toxic equivalency TEQ concentrations were calculated guided to World Health Organization-toxic equivalent factor WHO-TEF established in $2005^{[3]}$. The resulting values are presented in pg $\mathrm{WHO}_{2005}-\mathrm{TEQ} / \mathrm{g}$ whole weight (w.w.), by multiplying the concentration (ng/g) of each congener by its toxic equivalent factor WHO-TEF then summation values of 17 congeners to get the toxic equivalency 
concentration of $\mathrm{PCDD} / \mathrm{Fs}$ in the sample. It was assumed that non-detected isomer concentrations were equal to the limits of determination, as recommended by the European Regulation [24]. Detection and quantification limits, as well as, recoveries for all PCDD/Fs congeners were in good agreement with requirements laying down the sampling methods and the methods of the analysis for the official control of PCDD/Fs. For each run the samples were prepared including a method blank and quality control samples were performed.

\section{Results and discussion}

\section{PCDDs/Fs levels in orange samples on a fresh basis}

The mean levels measured by HRGC/MS of $17 \mathrm{PCDD} / \mathrm{F}$ congeners (pg/g) whole weight (w.w.), in the 18 orange samples collected from different markets in Egypt, are shown in Table (1). The results showed that the $\Sigma \mathrm{PCDD} / \mathrm{Fs}$ concentrations ranged from (0.4576 to $6.1600) \mathrm{pg} / \mathrm{g} \mathrm{w} . \mathrm{w}$. and the mean concentration is 1.8596 $\mathrm{pg} / \mathrm{g} \mathrm{w.w}$. The $\Sigma$ PCDDs concentrations ranged from ( 0.1848 to 4.4920$) \mathrm{pg} / \mathrm{g} \mathrm{w} . \mathrm{w}$. of the mean concentration $0.8827 \mathrm{pg} / \mathrm{g} \mathrm{W.w}$, while the $\Sigma$ PCDFs concentrations ranged from (0.4576 to 3.0971$) \mathrm{pg} / \mathrm{g} \mathrm{w.w.} \mathrm{of} \mathrm{the} \mathrm{mean}$ concentration $0.9769 \mathrm{pg} / \mathrm{g} \mathrm{w} . \mathrm{W}$.

The contribution of PCDD/F congeners is also studied and the results are presented in Figures 1 and 2. The results showed that the mean concentration of $\Sigma$ PCDFs (0.9769 pg/g w.w.) is slightly higher than of $\Sigma$ PCDDs (0.8827 pg/g w.w.) which contribute about $52.54 \%$ from the total PCDD/F contents in all analyzed samples. The congeners were descending contributed in orange samples as follows OCDD (1,2,3,4,6,7,8,9Octachlorodibenzo-p-dioxin), $\mathrm{HpCDF} \quad(1,2,3,4,6,7,8$ Heptachloro-dibenzofuran and 1,2,3,4,7,8,9Heptachlorodibenzofuran), OCDF $\quad(1,2,3,4,6,7,8,9-$ Octachlorodibenzofuran), $\quad \mathrm{HxCDF} \quad(1,2,3,4,7,8$ Hexachlorodibenzofuran, $\quad 1,2,3,6,7,8$ Hexachlorodibenzofuran, Hexachlorodibenzofuran

$2,3,4,6,7,8-$

chlorodibenzofuran),

Pentachlorodibenzofuran and 1,2,3,7,8,9-Hexa$\mathrm{PeCDF} \quad(1,2,3,7,8$ and 2,3,4,7,8-Pentachlorodibenzofuran), HpCDD $\quad(1,2,3,4,6,7,8-$ Heptachlorodibenzo-p-dioxin), TCDF $\quad(2,3,7,8$ Tetrachlorodibenzofuran), HxCDD (1,2,3,4,7,8Hexachlorodibenzo-p-dioxin, Hexachlorodibenzo-p-dioxin PeCDD $\quad(1,2,3,7,8$ Pentachlorodibenzo-p-dioxin) and TCDD (2,3,7,8-Tetrachlorodibenzo-p-dioxin) of the mean contributions to the total PCDD/F contents in all analyzed samples are about $30.06,15.33,13.62,9.71,7.13,6.97,6.72,5.33,3.57$ and $1.53 \%$, respectively, with mean concentrations about $0.559,0.285,0.253,0.181,0.133,0.130,0.125,0.099$, 0.066 and $0.028 \mathrm{ng} / \mathrm{g} \mathrm{w.w.,} \mathrm{respectively.}$

The results are in agreement with other reports in Europe in which the mean concentration of $\Sigma \mathrm{PCDF}$ is higher than SPCDDs $^{[25]}$ and the most dominant congener is $1,2,3,4,6,7,8,9-$-Octachlorodibenzo-p-dioxin (OCDD) ${ }^{[26]}$. The most dominant congener OCDD has been reported to be dominant in emission from domestic combustion [27]

Table (1): Mean, Minimum, Maximum and 90thpercentile concentrations (pg/g whole weight) of the PCDD/Fs congeners corresponding to their toxic equivalency concentrations (pgWHO-TEQ $2005 / \mathrm{g} \mathrm{w} . \mathrm{w}$.) in orange, $(\mathrm{n}=18)^{*}$.

\begin{tabular}{|c|c|c|c|c|c|c|c|c|}
\hline \multirow{2}{*}{ Congener } & \multicolumn{4}{|c|}{$\begin{array}{c}\text { Concentration (pg/g) whole } \\
\text { weight }\end{array}$} & \multirow{2}{*}{$\begin{array}{l}\text { Dioxin } \\
\text { WHO- } \\
T E f_{2005}\end{array}$} & \multicolumn{3}{|c|}{$\begin{array}{l}\text { Concentration pgWHO- } \\
\text { TEQ }_{2005} / \mathrm{g} \text { whole weight }\end{array}$} \\
\hline & Mean & Min & Max & $\begin{array}{c}90^{\text {th }} \\
\text { percentile }\end{array}$ & & Mean & Min & $\operatorname{Max}$ \\
\hline 2,3,7,8-Tetrachlorodibenzo-p-dioxin; $(2,3,7,8$-TCDD) & 0.0284 & 0.0048 & $\mathbf{0 . 0 7 2 0}$ & 0.0573 & 1 & $\mathbf{0 . 0 2 8 4}$ & 0.0048 & $\mathbf{0 . 0 7 2 0}$ \\
\hline 1,2,3,7,8-Pentachlorodibenzo-p-dioxin; (1,2,3,7,8-PeCDD) & 0.0664 & 0.0104 & 0.1408 & 0.1158 & 1 & 0.0664 & 0.0104 & $\mathbf{0 . 1 4 0 8}$ \\
\hline 1,2,3,4,7,8-Hexachlorodibenzo-p-dioxin; $(1,2,3,4,7,8-H x C D D)$ & $\mathbf{0 . 0 3 7 0}$ & 0.0088 & 0.1264 & $\mathbf{0 . 0 7 3 0}$ & $\mathbf{0 . 1}$ & $\mathbf{0 . 0 0 3 7}$ & 0.0009 & $\mathbf{0 . 0 1 2 6}$ \\
\hline 1,2,3,6,7,8-Hexachlorodibenzo-p-dioxin; (1,2,3,6,7,8-HxCDD) & $\mathbf{0 . 0 3 3 0}$ & 0.0088 & 0.1040 & $\mathbf{0 . 0 5 8 4}$ & 0.1 & $\mathbf{0 . 0 0 3 3}$ & 0.0009 & 0.0104 \\
\hline 1,2,3,7,8,9-Hexachlorodibenzo-p-dioxin; (1,2,3,7,8,9-HxCDD) & 0.0290 & 0.0072 & 0.0792 & 0.0541 & 0.1 & 0.0029 & 0.0007 & 0.0079 \\
\hline 1,2,3,4,6,7,8-Heptachlorodibenzo-p-dioxin; (1,2,3,4,6,7,8-HpCDD) & 0.1297 & 0.0208 & 0.5968 & 0.2504 & 0.01 & 0.0013 & 0.0002 & 0.0060 \\
\hline 1,2,3,4,6,7,8,9-Octachlorodibenzo-p-dioxin; (1,2,3,4,6,7,8,9-OCDD $)$ & 0.5592 & $\mathbf{0 . 0 3 3 6}$ & 3.6880 & $\mathbf{1 . 0 7 2 4}$ & 0.0003 & 0.0002 & 0.0000 & 0.0011 \\
\hline 2,3,7,8-Tetrachlorodibenzofuran; (2,3,7,8-TCDF) & 0.1249 & 0.0432 & 0.3533 & 0.2191 & 0.1 & $\mathbf{0 . 0 1 2 5}$ & 0.0043 & $\mathbf{0 . 0 3 5 3}$ \\
\hline 1,2,3,7,8-Pentachlorodibenzofuran; $(1,2,3,7,8-P e C D F)$ & 0.0660 & 0.0248 & $\mathbf{0 . 1 0 5 0}$ & 0.0928 & $\mathbf{0 . 0 3}$ & $\mathbf{0 . 0 0 2 0}$ & 0.0007 & $\mathbf{0 . 0 0 3 2}$ \\
\hline 2,3,4,7,8-Pentachlorodibenzofuran; $(2,3,4,7,8$-PeCDF $)$ & 0.0667 & $\mathbf{0 . 0 2 8 0}$ & 0.1264 & 0.1014 & 0.3 & 0.0200 & 0.0084 & $\mathbf{0 . 0 3 7 9}$ \\
\hline 1,2,3,4,7,8-Hexachlorodibenzofuran; $(1,2,3,4,7,8-H x C D F)$ & 0.0684 & 0.0184 & 0.1136 & 0.1038 & 0.1 & 0.0068 & 0.0018 & 0.0114 \\
\hline 1,2,3,6,7,8-Hexachlorodibenzofuran; $(1,2,3,6,7,8-\mathrm{HxCDF})$ & 0.0428 & $\mathbf{0 . 0 1 2 8}$ & 0.0672 & 0.0648 & 0.1 & 0.0043 & 0.0013 & 0.0067 \\
\hline 2,3,4,6,7,8-Hexachlorodibenzofuran; $(2,3,4,6,7,8-H x C D F)$ & 0.0399 & 0.0136 & 0.0744 & 0.0624 & 0.1 & 0.0040 & 0.0014 & 0.0074 \\
\hline 1,2,3,7,8,9-Hexachlorodibenzofuran; (1,2,3,7,8,9-HxCDF) & 0.0296 & 0.0072 & 0.0648 & 0.0534 & 0.1 & $\mathbf{0 . 0 0 3 0}$ & 0.0007 & 0.0065 \\
\hline 1,2,3,4,6,7,8-Heptachlorodibenzofuran; $(1,2,3,4,6,7,8-H p C D F)$ & 0.2361 & 0.0224 & 0.8445 & $\mathbf{0 . 5 8 1 4}$ & $\mathbf{0 . 0 1}$ & 0.0024 & 0.0002 & 0.0084 \\
\hline 1,2,3,4,7,8,9-Heptachlorodibenzofuran; $(1,2,3,4,7,8,9-H p C D F)$ & 0.0491 & 0.0134 & 0.1296 & 0.0846 & 0.01 & 0.0005 & 0.0001 & 0.0013 \\
\hline 1,2,3,4,6,7,8,9-Octachlorodibenzofuran; $(1,2,3,4,6,7,8,9-O C D F)$ & 0.2534 & 0.0156 & 0.8376 & 0.5366 & 0.0003 & 0.0001 & 0.0000 & 0.0003 \\
\hline Sum Polychlorodibenzo-p-dioxins (PCDDs) & 0.8827 & 0.1848 & 4.4920 & 1.5205 & & 0.1061 & 0.0187 & 0.2215 \\
\hline Sum Polychlorodibenzofurans (PCDFs) & 0.9769 & 0.2728 & 1.8968 & 1.6939 & & 0.0555 & 0.0222 & 0.0886 \\
\hline Sum Polychlorodibenzo-p-dioxins and furans (PCDD/Fs) & 1.8596 & 0.4576 & 6.1600 & 3.0971 & & 0.1616 & 0.0624 & $\mathbf{0 . 2 8 8 4}$ \\
\hline
\end{tabular}

*Number of orange samples $(\mathrm{n})=18$. 


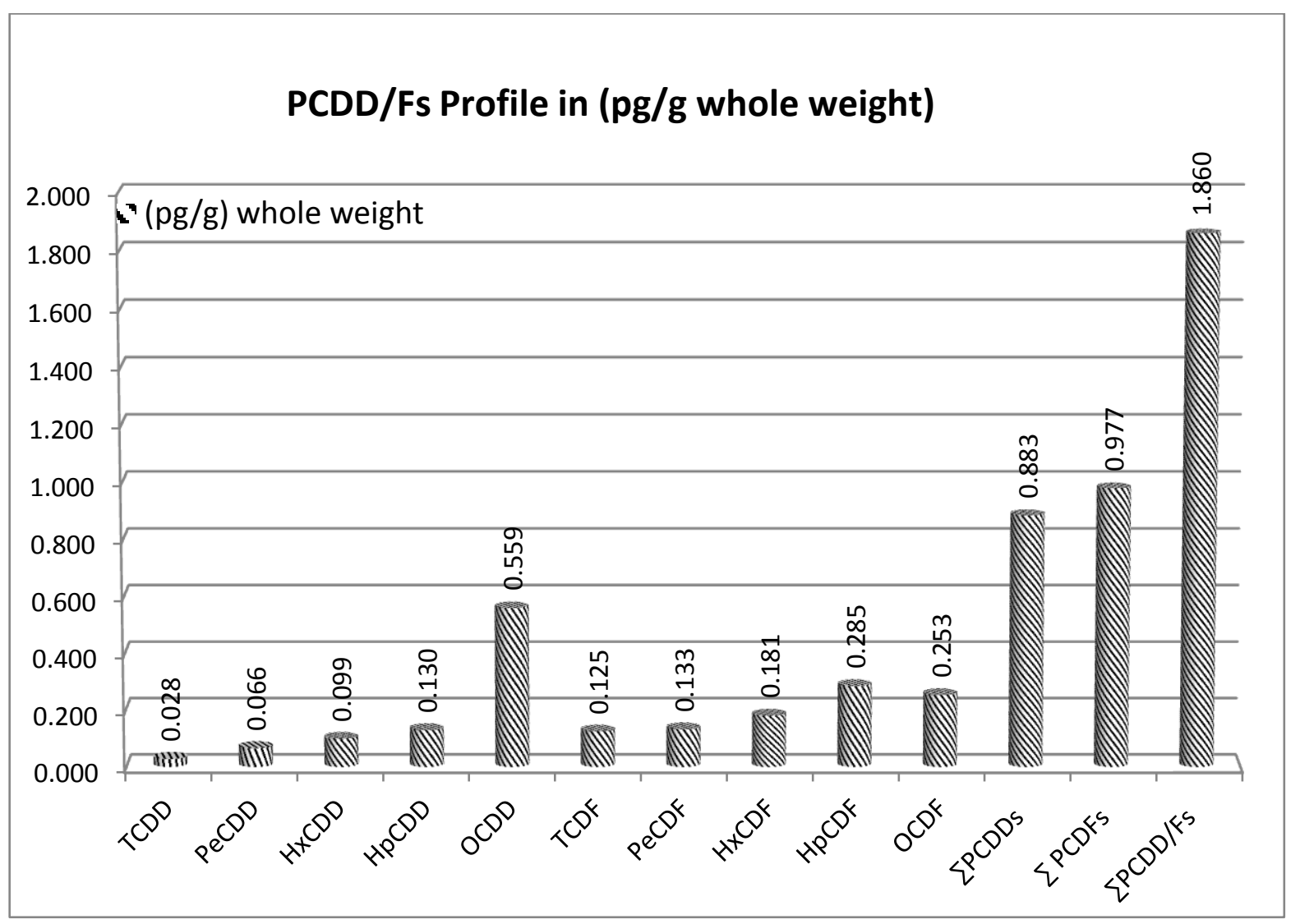

Fig (1): Mean concentrations of PCDDs/Fs profile in orange (pg/g w.w.).

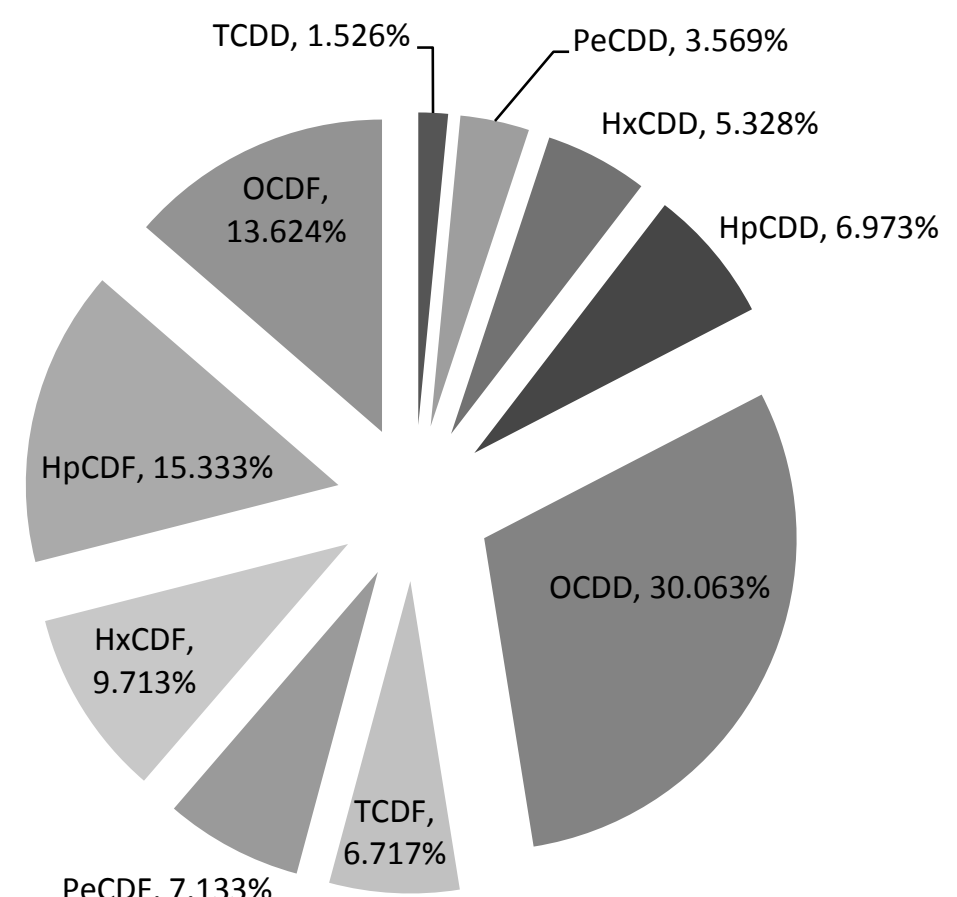

Fig (2): Contribution (\%) of PCDD/F congeners to the mean concentration of $\Sigma \mathrm{PCDD} / \mathrm{Fs}(\mathrm{pg} / \mathrm{g} \mathrm{w} . \mathrm{w}$.) in orange. 
PCDD/Fs (pg WHO-TEQ/g) levels in orange samples The results obtained from the analysis of seventeen 2,3,7,8-substituted congeners of PCCD/Fs in the orange samples multiplied by a toxic equivalency factor (TEF) [6] are shown in Table (1). The results showed that the toxic equivalency concentration of $\sum \mathrm{PCDD} / \mathrm{Fs}$ ranged from $(0.0624$ to 0.2884$)$ pgWHO-TEQ $2005 / g$ w.w. and the mean is $0.1616 \mathrm{pgWHO}-\mathrm{TEQ}_{2005} / \mathrm{g} \mathrm{w.w.} \mathrm{which} \mathrm{is}$ lower than the maximum permissible limits of Egyptian Standardization and European Community (0.30 pgWHO-TEQ $2005 / g$ w.w.) ${ }^{[24]}$. This study showed that the average toxic equivalency concentration of $\Sigma$ PCDDs (0.1061 pgWHO-TEQ ${ }_{2005} / \mathrm{g}$ w.w.) is higher than the average toxic equivalency concentration of $\Sigma$ PCDFs (0.0555pgWHO-TEQ $2005 / g \quad$ w.w.) which contributes about $65.66 \%$ of the total toxic equivalency concentration of $\sum \mathrm{PCDD} / \mathrm{Fs}$ in commercialized orange in Egypt.

The contribution of $\mathrm{PCDD} / \mathrm{F}$ congeners according to their toxic equivalency factor (TEF) is also studied and the results are presented in Figures 3 and 4. The congeners were descending contributed in orange samples as following PeCDD, TCDD, PeCDF, HxCDF, TCDF, HxCDD, HpCDF, HpCDD, OCDD and OCDF which contribute from the total toxic equivalency concentration of $\sum \mathrm{PCDD} / \mathrm{Fs}$ in analyzed samples about $41.08,17.56,13.60,11.18,7.73,6.13,1.76,0.80,0.10$ and $0.05 \%$, respectively, with mean concentrations about $0.066,0.028,0.022,0.018,0.013,0.010,0.003$,

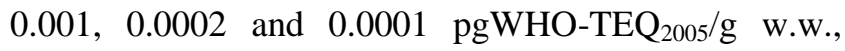
respectively.

Although OCDD showed the highest concentrations of total PCDD/Fs. in orange samples, it showed much lower TEQ concentration of total PCDD/Fs. The high chlorinated congeners, which exhibited the highest PCDD/F concentrations, did not account to a significant percentage of the WHO-TEQ content due to their relatively low WHO-TEF values as described in Figures 2 and 4.

\section{Dietary Intake of PCDD/Fs pg/g (TEQ) in orange samples}

Dietary exposure assessment combines food consumption data with data on the concentration of chemicals in food. The results of estimated dietary exposure then compared with the relevant health based guidance value for the food chemical of concern, if available, as part of the risk characterization.
Assessments may be undertaken for acute or chronic exposures, where acute exposure covers a period of up to 24 hours and chronic or long-term exposure covers average daily exposure over the entire lifetime ${ }^{[28]}$.

The general equation for both acute and chronic dietary exposure was:

Dietary exposure

$=\frac{\sum(\text { Concentration of chemical in food } \times \text { Food consumption })}{\text { Body weight }}$

In the chronic (long-term) risk assessment, the estimated dietary intake (EDI) for $\Sigma \mathrm{PCDD} / \mathrm{Fs}$ of the Egyptian consumer was compared to the relevant toxicological reference values, i.e. acceptable Daily Intake of Dioxin (ADI) set by (International Programme on Chemical Safety (IPCS)) which was derived after a full hazard characterization of the compound. The consumer is considered to be adequately protected if the estimated dietary intake of detected dioxin does not exceed the acceptable provisional tolerable daily intake.

The limit values as given in Table (2) were based on a TDI (total daily intake) value of body weight. The maximum dioxin concentration in orange should not exceed $0.30 \mathrm{pg}$ TEQ/g whole weight [24]. The consumption of Egyptian people for orange attained according to GEMS/Food is (38 g/person/day) ${ }^{[29]}$ which showed that the Estimated Daily Intake (EDI) of $\Sigma \mathrm{PCDD} / \mathrm{Fs}$ of the Egyptian consumer is 0.1023 (pg WHO-TEQ/kg body weight/day) lower than the WHO acceptable daily intake which is $4 \mathrm{pg}$ WHO-TEQ/ kg b.w/day ${ }^{[20]}$. Thus, orange should not be out on the market if the dioxin contamination exceeds this value. These figures are still below the safe limits as the TDI of sum $\mathrm{PCDD} / \mathrm{Fs}$ is (4 pg WHO-TEQ/person/day) according to the International Programme on Chemical Safety (IPCS).

\section{Conclusion}

The levels of PCDD/Fs were studied in commercialized orange in Egypt using High Resolution Gas Chromatography - High Resolution Mass Spectrometer (HRGC-HRMS).The results showed that the mean levels of PCDD/Fs measured by HRGC/MS multiplied by toxic equivalent factor (TEF) in orange was lower than the maximum permissible limits of Egyptian Standardization and European Community. The study showed that the dietary intake of the Egyptian consumer of orange was lower than the WHO acceptable daily intake.

Table (2): Estimated daily intake (EDI) of sum means concentration PCDD/Fs in orange.

\begin{tabular}{|c|c|c|c|c|c|}
\hline 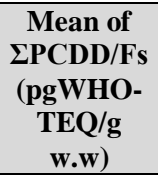 & $\begin{array}{c}\text { Food } \\
\text { consumption } \\
\text { g/day }^{*}\end{array}$ & $\begin{array}{c}\text { Estimated Daily Intake } \\
\text { (EDI) of } \\
\text { इPCDD/Fs (pg WHO-TEQ/ } \\
\text { Person/day) }\end{array}$ & $\begin{array}{c}\text { Estimated Daily } \\
\text { Intake (EDI) of } \\
\text { इPCDD/Fs (pg } \\
\text { WHO-TEQ/kg } \\
\text { b.w/day) }\end{array}$ & $\begin{array}{l}\text { Acceptable } \\
\text { Daily Intake of } \\
\text { Dioxin } \\
\text { (ADI) }\end{array}$ & Intake, \% \\
\hline 0.1616 & 38 & 6.1408 & 0.1023 & 4 & 2.5587 \\
\hline
\end{tabular}




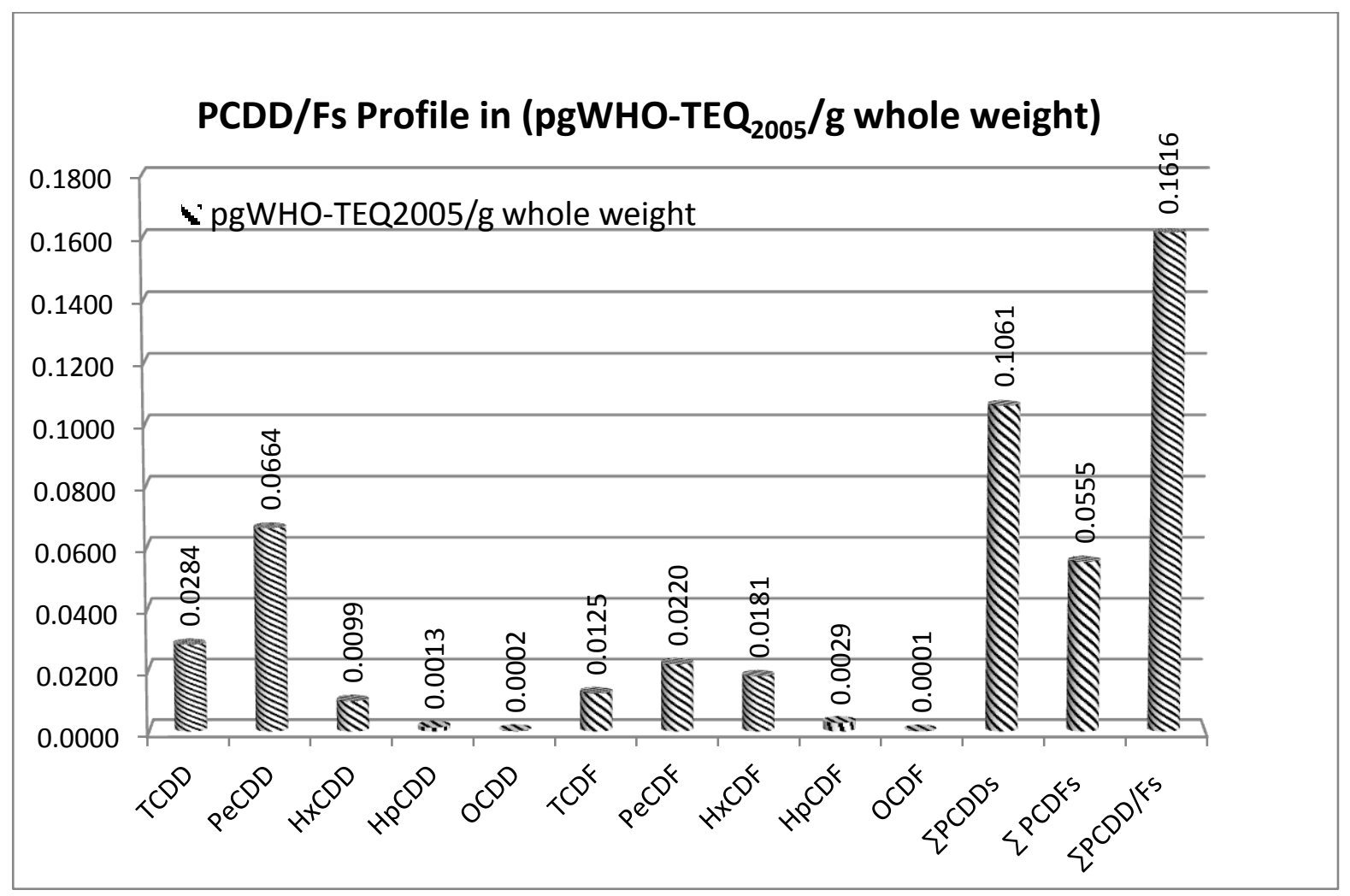

Fig (3): Mean concentrations of PCDDs/Fs profile in orange (pgWHO-TEQ $2005 / g$ w.w.).

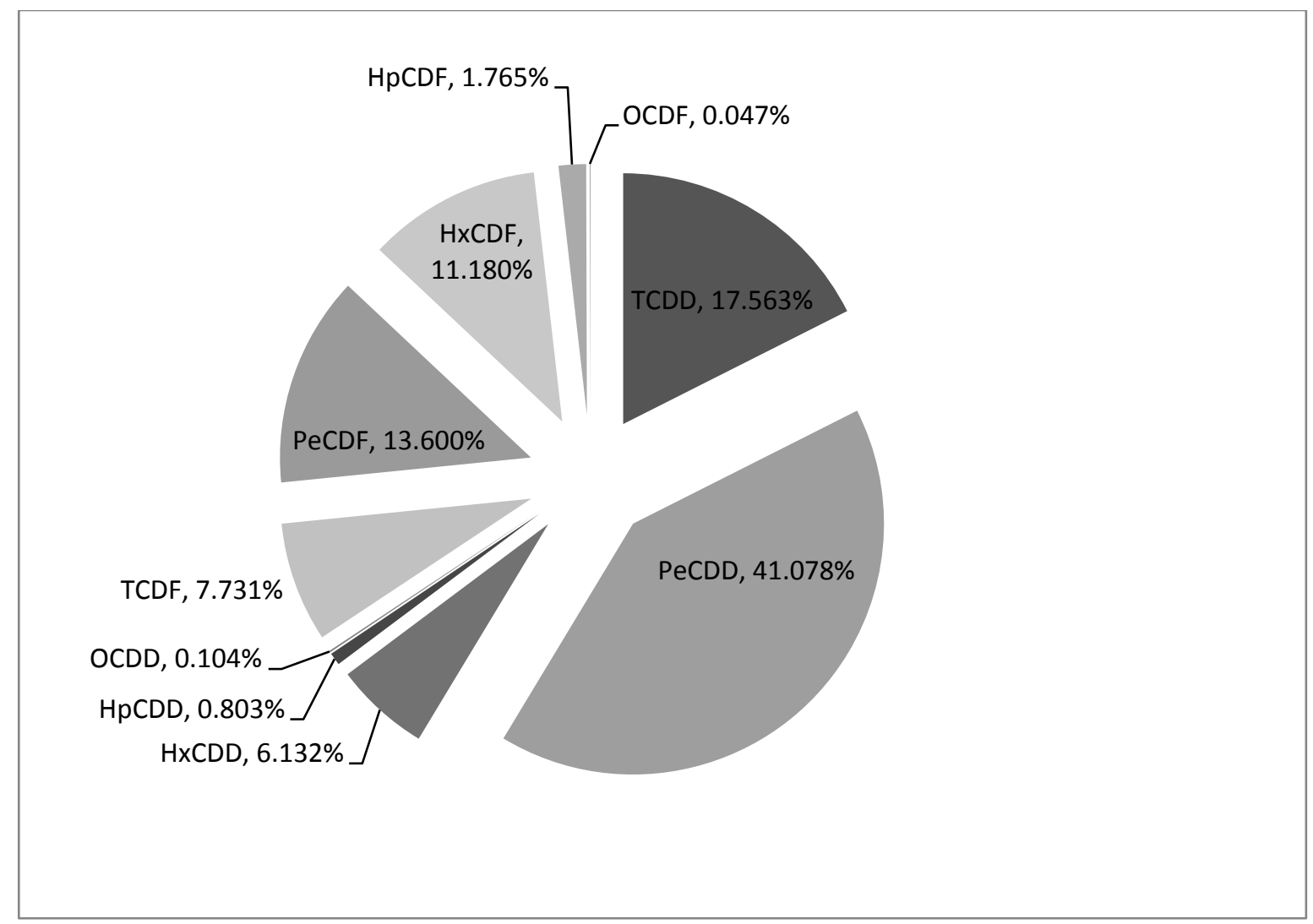

Fig (4): Contribution (\%) of PCDD/F congeners to the mean of $\Sigma \mathrm{PCDD} / \mathrm{Fs}\left(\mathrm{pgWHO}-\mathrm{TEQ}{ }_{2005} / \mathrm{g}\right.$ w.w.) in orange. 


\section{References}

1) Fiedler, H., Abad, E., van Bavel, B., de Boer, J., Bogdal, C. and Malisch, R. (2013). The need for capacity building and first results for the Stockholm Convention Global Monitoring Plan. Trends Anal. Chem., 46:72-84.

2) Gilpin, R. K., Wagel, D. J. and Solch, J. G. (2003). Production, distribution and fate of polychlorinated dibenzo $\mathrm{p}$ dioxins, dibenzofurans, and related organohalogens in the environment. In: Schecter, A., Gasiewicz, T.A. (Eds.), Dioxins and Health. Wiley- Interscience Hoboken, NJ, New Jersey, p. 952.

3) Van den Berg, M., Birnbaum, L. S., Denison, M., de Vito, M., Farland, W., Feeley, M., Fiedler, H., Hakansson, H., Hanberg, A., Haws, L., Rose, M., Safe, S., Schrenk, D., Tohyama, C., Tritscher, A., Tuomisto, J., Tysklind, M., Walker, N. and Pete, R. E. (2006). The 2005 world health organization reevaluation of human and mammalian toxic equivalency factors for dioxins and dioxin: like compounds. Toxicol. Sci., 93: 223-241.

4) Yang, Y.-H., Chang, Y.-S., Shin, D.-C., MG and Ikonomou (2002). Congener- distribution patterns and risk assessment of polychlorinated biphenyls, dibenzo-p- dioxins and dibenzofurans in Korea human milk. Chemosphere, 47:1087-1095.

5) Prashant, S., Kulkarni, J. and Afonso, C. A. M. (2008). Dioxins sources and current remediation technologies. Environ. Int., 34:139-153.

6) Sinkkonen, S. P. and Paasivirta, J. (2000). Degradation half-life times of PCDDs, PCDFs and PCBs for environmental fate modeling. s.l. Chemosphere, 40:943-949.

7) Travis, C. C. and Hattemer-Frey, H. A. (1987). Human exposure to 2,3,7,8- TCDD. Chemosphere, 16:2331-2342.

8) World Health Organization (1998). Assessment of the health risk of dioxins: reevaluation of the tolerable daily intake (TDI). WHO Consultation, Geneva, 25-29 May.

9) Liem, D. (1999). Basic aspects of methods for the determination of dioxins and PCBs in foodstuffs and human tissues. Trends Anal. Chem., 18: 429-439.

10) Focant, J.-F., Pirard, C., Thielen, C. and De Pauw, E. (2002). Levels and profiles of PCDDs, PCDFs and cPCBs in Belgian breast milk. Estimation of infant intake. Chemosphere, 48:763770.

11) The United States Department of Agriculture (USDA) Foreign Agricultural service (2015). Egypt is Likely to Remain World's Orange Largest Exporter. Egypt, Citrus Annual report 2015:1-8.

12) Pluim, H. J., de Vijlder, J. J., Olie, K., Kok, J. H., Vulsma, T., van Tijn, D. A., van der Slikke, J. W. and Koppe, J. G. (1993). Effects of pre- and postnatal exposure to chlorinated dioxins and furans on human neonatal thyroid hormone concentrations.
Environ. Health Perspect, 101: 504-508.

13) Environmental Protection Agency (1994). EPA/600/BP-92/001c. Health Assessment Document For 2,3,7,8-Tetrachlorodibenzo-p-dioxin (TCDD) And Related Compounds. Washington DC, National Service Center for Environmental Publications (NSCEP), 3:1-128.

14) Rylander, L., Stromberg, U., Dyremark, E., Ostman, C., Nilsson Ehle, P. and Hagmar, L. (1998). Polychlorinated biphenyls in blood plasma among Swedish female fish consumers in relation to low birth weight. Am. J. Epidemiol, 147:493-502.

15) Watanabe, S., Kitamura, K. and Nagahashi, M. (1999). Effects of dioxins on human health: a review. J. Epidemiol., 9:1-13.

16) Guo, Y. L., Hsu, P. C., Hsu, C. C. and Lambert, G. H. (2000). Semen quality after prenatal exposure to polychlorinated biphenyls and dibenzofurans. s.l. Lancet, 356:1240-1241.

17) Kogevinas, M. (2001). Human health effects of dioxin: cancer, reproductive and endocrine system effects. Hum. Reprod., Update 7:331-339.

18) Gilman, A., Newhook, R. and Birmingham, B. (1991). An updated assessment of the exposure of Canadians to dioxins and furans. Chemosphere, 23: 1661-1667.

19) Zhang, J., Jiang, Y., Zhou, J., Fang, D., Jiang, J. and Liu, G. (2008). Concentrations of PCDD/PCDFs and PCBs in retail foods and an assessment of dietary intake for local population of Shenzhen in China. Environ. Int., 34:799-803.

20) World Health Organization (2000). Assessment of the health risk of dioxins: reevaluation of the tolerable daily intake (TDI). In: van Leeuwen, F.X.R. and Younes, M.M. (Eds.), Food Add. Contam., 17: 4.

21) Scientific Committee on Food (2001). Opinion of the SCF on the risk assessment of dioxins and dioxin-like PCBs in food, SCF/CS/CNTM/DIOXIN/8 Final. Brussels (Belgium).

22) Joint FAO/WHO Food Standards Programme Codex Alimentarius Commission (2003). Draft Revised Guidelines on Good practice in Residue Analysis (ALINORM 03/24A) Appendix II, P. 46 79 (at step 8 of the codex procedure).

23) U.S.A Environmental Protection Agency (1994). Method 1613(b) Tetra- through octa Chlorinated Dioxins and Furans by Isotope Dilution HRGC/HRMS.

24) Commission of the European Communities (2013). Commission recommendation on the reduction of the presence of dioxins, furans and PCBs in feed and food. Official Journal of the European Union, Recommendation (2013/711/EU), 323:37-39.

25) Perello, G., Gomez-Catalan, J., Castell, V., Llobet, J. M. and Domingo, J. L. (2012). 
Assessment of the temporal trend of the dietary exposure to PCDD/Fs and PCBs in Catalonia, over Spain: Health risks. Food and Chemical Toxicology, 50:399-408.

26) Domingo, J. L., Perelló, G., Nadal, M. and Schuhmacher, M. (2012). Dietary intake of polychlorinated dibenzo-p-dioxins and dibenzofurans (PCDD/Fs) by a population living in the vicinity of a hazardous waste incinerator, Assessment of the temporal trend. Environment International, 50:22-30.
27) Wevers, M., De Fre', R. and Desmedt, M. (2004). Effect of backyard burning on dioxin deposition and air concentrations. Chemosphere, 54:1351-1356.

28) Joint FAO/WHO Expert Meeting on Dietary Exposure Assessment Methodologies for Residues of Veterinary Drugs (7-11 November 2011). Rome, Italy, ISBN: 978- 92- 4-156449- 6.

29) Global Environment Monitoring System-Food Contamination Monitoring and Assessment Program (GEMS/Foods) (2006). Program of food safety and food aid, Geneva, Switzerland. 